\title{
Angiotensin Converting Enzyme (ACE) Inhibitory Activity of Peptide Fraction of Germinated Pigeon Pea (Cajanus cajan (L.) Millsp.)
}

\author{
Ketut Ratnayani $^{1, *}$, I Ketut Suter ${ }^{2}$, Nyoman Semadi Antara ${ }^{3}$, and I Nengah Kencana Putra ${ }^{2}$ \\ ${ }^{1}$ Department of Chemistry, Faculty of Natural Sciences, Udayana University, Denpasar 80361, Indonesia \\ ${ }^{2}$ Department of Food Science and Technology, Faculty of Agricultural Technology, Udayana University, Denpasar 80361, Indonesia \\ ${ }^{3}$ Department of Agroindustrial Technology, Faculty of Agricultural Technology, Udayana University, Denpasar 80361, Indonesia
}

${ }^{*}$ Corresponding author:

tel: $+62-361-703137$

email:ketut_ratnayani@unud.ac.id

Received: July 31, 2018

Accepted: December 11, 2018

DOI: $10.22146 /$ ijc.37513

\begin{abstract}
During the germination process, seeds can release various types of peptides due to the degradation of storage proteins. Some of these peptides can have biological activity (bioactive peptides). The objective of this study was to determine the ACE inhibitory activity of germinated pigeon pea peptide extract at various germination times and to carry out the fractionation to the extract to get the most active peptide fraction. The results showed that the highest activity of peptide extract was found on the $4^{\text {th }}$-day germination of pigeon pea with an $I_{50}$ value of $63.46 \mu \mathrm{g} / \mathrm{mL}$. The peptide extract was further fractionated by centrifugal ultrafiltration method and it was found that the peptide fraction $<3 \mathrm{kDa}$ had the highest ACE inhibitory activity with an $\mathrm{IC}_{50}$ value of $57.79 \mu \mathrm{g} / \mathrm{mL}$. The result of identification with the LCMS method to the fraction was able to detect 4 types of the peptide with a molecular weight of 230.304, 294.303, 441.436, and $570.591 \mathrm{Da}$. These results suggested that the peptide fraction of germinated pigeon pea has the potency as an ACE inhibitory nutraceutical.
\end{abstract}

Keywords: pigeon pea; peptide fraction; ACE inhibitory; germination

\section{INTRODUCTION}

Angiotensin Converting Enzyme (ACE) has a major physiological role in the regulation of blood pressure. Increasing of the blood pressure will be hampered if the ACE activity is inhibited by an inhibitor compound (ACE inhibitor). Thus, ACE inhibitors are usually used as a useful therapeutic approach for the treatment of hypertensive diseases. Natural bioactive peptide ACE inhibitors from food are of high interest and have been widely studied.

The bioactive peptide is a short oligopeptide with a specific amino acid sequence, generally containing 2-20 amino acids and has a molecular weight of less than 6000 Dalton ( $\mathrm{Da})$, which has biological activity after being released from its parent protein [1]. Several studies have shown that food from both animal and vegetable foods is an important source of bioactive peptides. Sources of bioactive peptides from plants include cereals, pseudocereals (buckwheat and amaranth), legumes and others. The presence of bioactive peptides in cereals and legumes can contribute to increase their food protein quality value and add its functionality [2].

Various natural processes involving protein hydrolysis have been studied to determine the ability of these processes in generating bioactive peptides, one of them is the germination process. The germination process can make significant changes in the biochemical properties of the seeds due to the activation of enzymatic processes that convert storage macromolecules into nutrients for seed growth. The germination method can be used to modify the presence of nutrients and antinutrients in seeds [3]. During the germination, the storage proteins are degraded by different types of protease [4]. Thus, the germination process has the potency to produce bioactive peptides directly as a product of the hydrolysis of storage proteins by endogenous proteases in seeds.

Based on the literature searching, to date, there are 
only a few studies that explore the potency of the bioactive peptide of pigeon pea (Cajanus cajan (L.) Millsp.). Singh and Jambunathan [5] reported that the protein fraction from cotyledon of pigeon pea contains various types of hydrophobic amino acids which could potentially play a role in ACE inhibitory activity. Some researchers also had reported the ability of germinated seeds to produce bioactive peptides. Mandal et al. [6], identified and refined small molecular weight peptides $(0.5$ to $3 \mathrm{kDa})$ produced at various germination phases of mung beans (Vigna radiata (L) Wilczek, sonali b1) by chromatography and ultrafiltration methods. Bamdad et al. [7] have proved that germination of lentils (Lens culinaris Medik cv. Gachsaran) was able to generate bioactive peptide directly and obtained ACE inhibitory peptide extract with activity as much as $84.3 \%$.

This study aimed to determine the ACE inhibitory activity of pigeon pea peptide extract at various germination times and to fractionate the peptide component by centrifugal ultrafiltration method. The peptide fraction with the highest ACE inhibitory activity was then characterized by $\mathrm{IC}_{50}$ value, amino acid composition, and peptide molecular weight profile (LCMS method).

\section{- EXPERIMENTAL SECTION}

\section{Materials}

Pigeon pea was purchased from a local market in Semarapura, Klungkung District, Bali. The chemicals used include, $\mathrm{Na}_{2} \mathrm{HPO}_{4}$, citric acid, $\beta$-mercaptoethanol, $\mathrm{NaOH}, \mathrm{HCl}$, Angiotensin Converting Enzyme (ACE) from rabbit lung (Sigma-Aldrich), Hippuryl-histidylleucine (HHL; substrate for ACE) (Sigma-Aldrich), boric acid, ethyl acetate, $\mathrm{NaCl}, \mathrm{CuSO}$, sodium potassium tartrate, tryptone, Amicon ultrafiltration membrane filter (with MWCO $3 \mathrm{kDa}$ and $10 \mathrm{kDa}$ ) (Sigma-Aldrich), acetonitrile and formic acid.

\section{Instrumentation}

Instruments used in this study were Shimadzu UV/Vis spectrophotometer model UV-2600, Alliance HPLC system (Waters) and UPLC-MS-TOF (Model Xevo G2-S QT, Waters).

\section{Procedure}

\section{Pigeon pea germination process}

The germination process was carried out following the modified method of Bamdad et al. [7]. A total of $500 \mathrm{~g}$ of sorted pigeon peas were soaked for $30 \mathrm{~min}$ with $0.07 \%$ sodium hypochlorite (ratio 1:5). After rinsing three times with tap water, the pigeon peas were then added with warm water temperature $50^{\circ} \mathrm{C}$ (ratio 1:3) at first and then left to be submerged at room temperature for $5 \mathrm{~h}$. After the imbibition, the seed was drained and placed in a petri dish lined with wet filter paper. Pigeon pea was then germinated in a germinator at $25{ }^{\circ} \mathrm{C}$ with $99 \%$ humidity and sprayed with distilled water every $24 \mathrm{~h}$ to keep moisture. Variation of germination time was done on days $0,1,2,3,4$ and 5 with three repetitions. The resulting sprouts were stored at $-20^{\circ} \mathrm{C}$ for $24 \mathrm{~h}$ to stop the germination process. The sprouts were dried using the oven at $45^{\circ} \mathrm{C}$ for $24 \mathrm{~h}$. The dried sprouts were blended and sieved using a 60 mesh sieve to obtain germinated pigeon pea flour.

\section{Extraction of peptides from germinated pigeon pea flour}

The peptide extraction process was carried out following the modified method of Bamdad et al. [7]. Each of germinated pigeon pea flour samples (at various germination times) were mixed with $25 \mathrm{mM}$ citratephosphate buffer ( $\mathrm{pH} 5$ containing $2 \mathrm{mM} \quad \beta$ mercaptoethanol) at a ratio of $1: 8$ and were homogenized using vortex for $1 \mathrm{~min}$. This mixture was further filtered with Whatman no 1 filter paper, and the filtrate was centrifuged at $3000 \times \mathrm{g}$ for $15 \mathrm{~min}$ at $4{ }^{\circ} \mathrm{C}$. The supernatant was subsequently freeze-dried and called as germinated pigeon pea peptide extract (GPPE).

\section{Determination of peptide concentration of the GPPE}

To eliminate the content of the higher molecular weight protein (deproteinization), before the peptide concentration of GPPE sample was analyzed, the GPPE sample was first filtered by passing it into the $10 \mathrm{kDa}$ ultrafiltration membrane. The obtained filtrate (contained peptides with molecular weight $<10 \mathrm{kDa}$ ) was then analyzed its peptide concentration by Biuret method at $540 \mathrm{~nm}$ using tryptone standard solution [8]. 


\section{Determination of ACE inhibitory activity of the GPPE}

ACE inhibitory activity of samples was measured by UV Spectrophotometers based on the rate of formation of hippuric acid which is a product of the conversion of HHL substrate by ACE enzyme using Chusman and Cheung method with some modification [9]. For each measurement, $20 \mu \mathrm{L}$ samples and $50 \mu \mathrm{L} 100 \mathrm{mM}$ HHL (contained $300 \mathrm{mM} \mathrm{NaCl}$ ) were incubated with $10 \mu \mathrm{L}$ ACE $100 \mathrm{mU} / \mathrm{mL}$ at $37^{\circ} \mathrm{C}$ for $30 \mathrm{~min}$. The reaction was stopped by addition of $100 \mu \mathrm{L} 1 \mathrm{~N} \mathrm{HCl}$, then $1 \mathrm{~mL}$ of ethyl acetate was added and homogenized using vortex for $30 \mathrm{~s}$, and then centrifuged at $5000 \mathrm{rpm}$ for $10 \mathrm{~min}$. A total of $750 \mu \mathrm{L}$ supernatant (top layer) was taken and dried at $140{ }^{\circ} \mathrm{C}$ for $10 \mathrm{~min}$. The residue obtained from the drying product was dissolved with $2 \mathrm{~mL} 1 \mathrm{M} \mathrm{NaCl}$ and the absorbance was read at $228 \mathrm{~nm}$.

ACE inhibitory activity $(\%)=\frac{(\mathrm{Ac}-\mathrm{As})}{(\mathrm{Ac}-\mathrm{Ab})} \times 100 \%$

where, $\mathrm{Ac}=$ absorbance of the control; $\mathrm{As}=$ absorbance of the sample; $\mathrm{Ab}=$ absorbance of the blank.

\section{Fractionation of ACE inhibitory peptide of the most active GPPE}

The ACE inhibitory peptide of GPPE was fractionated by a series of sequential filtration based on the size of the peptide using the centrifugal ultrafiltration method according to the method employed by Siow and Gan [10] with some modification. The ultrafiltration method was performed using a membrane filter (Amicon, Millipore) with MWCO 10 and $3 \mathrm{kDa}$. The sample was first passed into a filter with a $10 \mathrm{kDa}$ MWCO membrane by centrifugation at $7000 \times \mathrm{g}$. The resulting retentate was then collected as a fraction of $>10 \mathrm{kDa}$. The resulting filtrate was then passed through a filter with a $3 \mathrm{kDa}$ MWCO membrane by centrifugation at $7000 \times \mathrm{g}$. The retentate was collected as a fraction of $3-10 \mathrm{kDa}$, while the obtained filtrate was collected as a fraction of $<3 \mathrm{kDa}$. Thus, there will be 3 types of peptide fraction which was distinguished by its molecular weight size such as, fraction $>10 \mathrm{kDa}$, fraction 3-10 kDa and fraction $<3 \mathrm{kDa}$. Each of the resulting peptide fractions was further freeze-dried.

\section{Determination of total amino acid composition}

The total amino acid composition of the sample was analyzed based on the procedure described on Waters [11]. The sample was analyzed by hydrolyzing the sample with $6 \mathrm{~N} \mathrm{HCl}$, and then the hydrolysis results were derivatized with AccQ Fluorine Reagent Kit. A total of $5 \mu \mathrm{L}$ of this derivatization sample was then injected into the HPLC ALLIANCE system, using two mobile phases (buffer A and acetonitrile), AccQ.Tag Waters's column and a fluorescence detector. HPLC measurement conditions were as follows: column temperature $37^{\circ} \mathrm{C}$, column length $250-395 \mathrm{~nm}$, gain 10 , mobile phase flow rate of $1.05 \mathrm{~mL} / \mathrm{min}$.

\section{Molecular weight profile analysis of peptide molecules on the peptide fraction}

The peptide fraction with the highest ACE inhibitory activity was then analyzed by the UPLC-MSTOF method (Model Xevo G2-S QT, Waters, USA). A total of $5 \mu \mathrm{L}$ samples were injected into the ACQUITY UPLC @BEH C18 $(1.7 \mu \mathrm{m} 2.1 \times 50 \mathrm{~mm})$ column. The mobile phase used was solvent A (acetonitrile and $0.05 \%$ formic acid) and solvent $B$ (water and formic acid $0.05 \%$ ), with a flow rate of $0.2 \mathrm{~mL} / \mathrm{min}$ (step gradient). Positive ions were recorded with a mass range of 50 $3000 \mathrm{~m} / \mathrm{z}$. The resulting data was processed by Masslynx software to obtain molecular formulas from positive ions and fragmentation results, which was further traced to the structure of the compound based on a database available online through ChemSpider or Massbank websites as search engines [12-13].

\section{- RESULTS AND DISCUSSION}

\section{Peptide Concentration of Germinating Pigeon Pea Peptide Extract (GPPE) with a Variation of Germination Time}

During germination, protein storages are hydrolyzed by proteases forms a set of short peptides to be translocated to growing embryos for nutritional supplies. Endopeptidase degrades storage proteins resulting in peptides subsequently degraded by exopeptidase resulting in free amino acids [14]. Based on the general morphological observation on the pigeon pea germination process in this study, it showed that on the $1^{\text {st }}$ day of germination, the radicle tip has begun to appear, 
Table 1. Peptide concentration of the GPPE with a variation of germination time

\begin{tabular}{lc}
\hline Germination Time & Peptide Concentration $(\mathrm{mg} / \mathrm{mL})$ \\
\hline Control & $5.78 \pm 0.09^{\mathrm{b}}$ \\
$1^{\text {st }}$ day & $6.93 \pm 0.12^{\mathrm{d}}$ \\
$2^{\text {nd }}$ day & $6.32 \pm 0.12^{\mathrm{c}}$ \\
$3^{\text {rd }}$ day & $7.64 \pm 0.14^{\mathrm{e}}$ \\
$4^{\text {th }}$ day & $6.49 \pm 0.06^{\mathrm{c}}$ \\
$5^{\text {th }}$ day & $5.25 \pm 0.14^{\mathrm{a}}$ \\
\hline
\end{tabular}

Values are expressed as means \pm sd. ${ }^{a-e}$ Means the column by different letters are significantly different $(\mathrm{P}<0.05)$

while the peak period of germination occurred on the $3^{\text {rd }}$ day. Each germinated pigeon pea with a variation of germination time was then extracted to get the GPPE and their peptide concentration was shown in Table 1.

According to Table 1, showed that the highest peptide concentration of GPPE was found on the $3^{\text {rd }}$ day of germination, after that it decreased on the $4^{\text {th }}$ day and $5^{\text {th }}$ day. From $2^{\text {nd }}$ day there was an increasing peptide concentration until it reached the highest value on the $3^{\text {rd }}$ day which is the peak period of germination. This pattern of peptide concentration was in accordance with the germination of mungbean studied by Mandal et al. [6], who has examined the distribution of mungbean germination peptide profile and concluded that peptide profiles during germination could be divided into two main groups namely "housekeeping peptide" and "peak germination peptide". Housekeeping peptides continuously appeared throughout the germination period while the second group appeared only in the peak period of germination. In this study on pigeon pea germination, it can be concluded that starting on the $1^{\text {st }}$ day has been generated "peak germination peptide" until the $3^{\text {rd }}$ day. After the $3^{\text {rd }}$ day, there was a decrease in peptide concentration due to the peak period of germination has been passed, so that these peptides group began to be degraded into free amino acids, while their "housekeeping peptide" were still not degraded.

\section{ACE Inhibitory Activity of the GPPE with a Variation of Germination Time}

The result of ACE inhibitory activity determination of GPPE at various germination times can be seen in Table 2, which showed that there was an increase in ACE
Table 2. ACE inhibitory activity of GPPE with a variation of germination time

\begin{tabular}{lc}
\hline Germination Times & ACE Inhibitory Activity $(\%)$ \\
\hline Control & $22.22 \pm 0.64^{\mathrm{a}}$ \\
$1^{\text {st }}$ day & $32.18 \pm 3.40^{\mathrm{b}}$ \\
$2^{\text {nd }}$ day & $36.80 \pm 3.02^{\mathrm{bc}}$ \\
$3^{\text {rd }}$ day & $44.03 \pm 2.01^{\mathrm{c}}$ \\
$4^{\text {th }}$ day & $72.43 \pm 3.69^{\mathrm{e}}$ \\
$5^{\text {th }}$ day & $54.66 \pm 3.03^{\mathrm{d}}$ \\
\hline
\end{tabular}

Values are expressed as means $\pm \mathrm{sd} .{ }^{\mathrm{a}-\mathrm{e}}$ Means the column by different letters are significantly different $(\mathrm{P}<0.05)$

inhibitory activity with the increase of germination time which reached the highest peak at the $4^{\text {th }}$ day germination and it began to decline at the $5^{\text {th }}$ day.

Compared to the peptide concentration as seen in Table 1, the elevation of ACE inhibitory activities (showing that the highest ACE inhibitory activity was obtained at the $4^{\text {th }}$ day) is not in line with the elevation of peptide concentration (where the highest concentration was obtained at the $3^{\text {rd }}$ day). Although peptide concentration at the $4^{\text {th }}$ day was not as high as at the $3^{\text {rd }}$ day, the size of the peptide molecule would be shorter because there has been further degradation of the peptide by endogenous protease activity resulting in shorter peptides and free amino acids. It has already reported that the ACE inhibitory activity of bioactive peptide was determined by the composition and amino acid sequence of the peptide [2]. The $4^{\text {th }}$ day germination of pigeon pea was found to be able to generate peptide extract with the highest ACE inhibitory activity may be due to the peptide extract contained peptide components with the characteristic of the molecular weight, composition and amino acid sequence which was the most potential as an ACE inhibitor. Bamdad et al. [7] have found that the germination on the $5^{\text {th }}$ day of lentils (Lens culinaris Medik, cv. Gachsaran) was able to generate peptide extract with the highest ACE inhibitory activity.

\section{Fractionation of ACE Inhibitory Peptide of the Most Active GPPE (4 ${ }^{\text {th }}$ Day Germination)}

The GPPE with the highest ACE inhibitory activity ( $4^{\text {th }}$ day germination) was then fractionated based on their molecular size by centrifugal ultrafiltration method to obtain three fraction types namely: fraction $>10 \mathrm{kDa}$, 
3-10 kDa, and $<3 \mathrm{kDa}$. The ACE inhibitory activity of 3 types of fractions obtained was then determined as shown in Table 3.

Based on Table 3, it can be concluded that the fraction $<3 \mathrm{kDa}$ had a much higher ACE inhibitory activity than other fractions with higher molecular weight. This suggested that ACE inhibitory peptides contained in the $4^{\text {th }}$ day GPPE were dominated by short peptides of less than $3 \mathrm{kDa}$. This is also supported by the data in Table 4 which showed that the comparison of $\mathrm{IC}_{50}$ value between peptide extract before and after fractionation which was not much different, before fractionation the $\mathrm{IC}_{50}$ value was $63.46 \mu \mathrm{g} / \mathrm{mL}$ and after fractionation $(<3 \mathrm{kDa})$ the $\mathrm{IC}_{50}$ value was decreased to $57.79 \mu \mathrm{g} / \mathrm{mL}$.

\section{Characterization of Peptide Fraction $<3$ kDa}

The fraction $<3 \mathrm{kDa}$ as the peptide fraction with the highest activity was then characterized its amino acid composition (HPLC method) as shown in Table 5 and also the molecular weight profile of the peptide component by the LCMS method (Table 6). The data in Table 5 exhibited that glutamic acid was the principal amino acid type in the peptide fraction $<3 \mathrm{kDa}$. The other three dominant amino acids were aspartic acid, phenylalanine, and serine. Based on Table 5, in terms of the amino acid group, the acidic amino acid and the hydrophobic amino acid group were present in sufficient quantities. The hydrophobic amino acid group has a higher content than the polar group. The literature study showed that the relatively high presence of branching hydrophobic amino acid residues (proline) and aromatic amino acid residues (phenylalanine) is related to the ACE inhibitory activity [15-16]. This amino acid composition profile indicated that the presence of hydrophobic amino acids in the pigeon pea peptide fraction maybe played a role in determining its ACE inhibitory activity.

The molecular weight profile of peptides component was identified using LC-MS analysis based on the ratio $(\mathrm{m} / \mathrm{z})$ and mass spectra analysis of fragment ions derived from the precursor ions during fragmentation. Based on total ion chromatogram of analysis with the LCMS method using C18 column (Fig. 1), it showed that the peaks were appearing at low retention times that mostly under $6 \mathrm{~min}$. This indicates that the peptide fraction of

Table 3. The ACE inhibitory activity of fractionation product of $4^{\text {th }}$ day GPPE

\begin{tabular}{lc}
\hline Peptide Fraction & ACE Inhibitory Activity (\%) \\
\hline$>10 \mathrm{kDa}$ & $3.06 \pm 1.27^{\mathrm{a}}$ \\
$10-3 \mathrm{kDa}$ & $8.43 \pm 2.04^{\mathrm{a}}$ \\
$<3 \mathrm{kDa}$ & $86.97 \pm 2.04^{\mathrm{b}}$
\end{tabular}

Values are expressed as means \pm sd. ${ }^{\mathrm{a}-\mathrm{b}}$ Means the column by different letters are significantly different $(\mathrm{P}<0.05)$

Table 4. Comparison of $\mathrm{IC}_{50}$ values of $4^{\text {th }}$ day GPPE before and after fractionation

\begin{tabular}{lc}
\hline Sample & $\mathrm{IC}_{50}$ value $(\mu \mathrm{g} / \mathrm{mL})$ \\
\hline Before fractionation & 63.46 \\
After fractionation $(<3 \mathrm{kDa})$ & 57.79 \\
\hline
\end{tabular}

Table 5. The amino acid composition of $<3 \mathrm{kDa}$ fraction of germinated pigeon pea $(\mathrm{g} / 100 \mathrm{~g})$

\begin{tabular}{lclc}
\hline Amino Acid Type & $\mathrm{g} / 100 \mathrm{~g}$ & Amino Acid Type & $\mathrm{g} / 100 \mathrm{~g}$ \\
\hline Acidic Group : & & Hydrophobic Group: & \\
Aspartic Acid(Asp/D) & $0.38^{*}$ & Alanine (Ala/A) & 0.15 \\
Glutamic Acid(Glu/E) & $1.08^{*}$ & Valine (Val/V) & 0.15 \\
Polar Group : & & Phenylalanine (Phe/F) & 0.32 \\
Serine (Ser/S) & 0.18 & Isoleucine (Ile/I) & 0.08 \\
Tyrosine (Tyr/Y) & 0.05 & Leucine (Leu/L) & 0.10 \\
Threonine (Thr/T) & 0.10 & Proline (Pro/P) & 0.18 \\
Basic Group : & & Glycine (Gly/G) & 0.10 \\
Arginine (Arg/R) & 0.08 & & \\
Histidine (His/H) & 0.08 & & \\
Lysine (Lys/K) & 0.05 & & \\
*This value describes the total number of Asp include Asn, and the total number of Glu include Gln
\end{tabular}




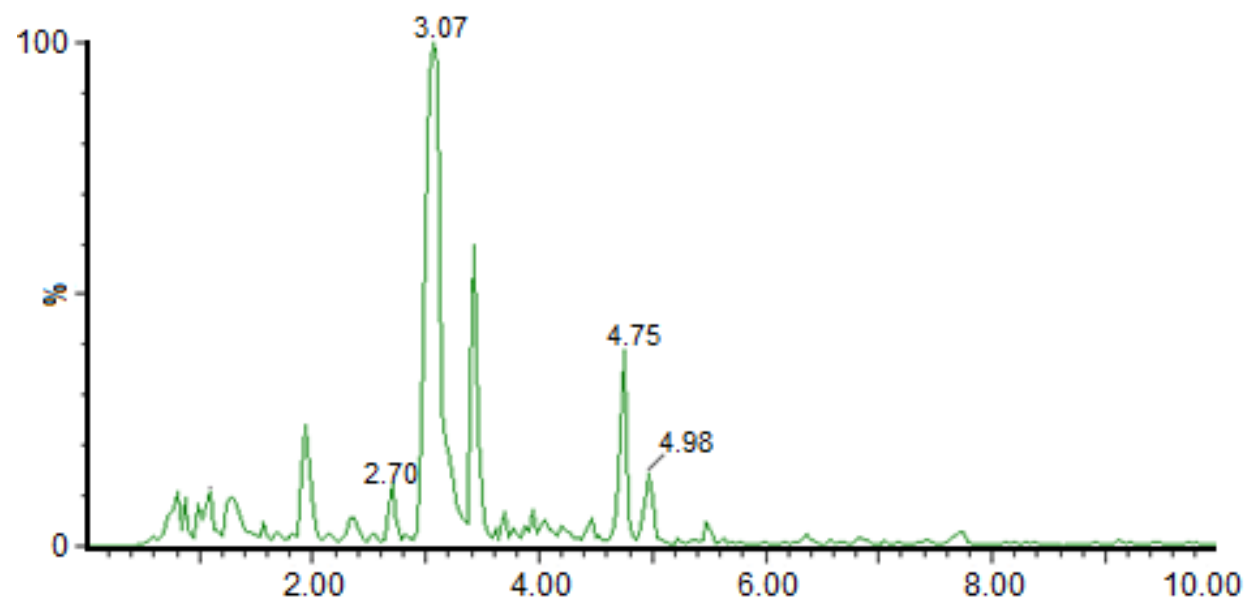

Fig 1. Total chromatogram ions of peptide fraction $<3 \mathrm{kDa}$ (RP-UPLC-MS-TOF)

Table 6. The molecular weight of peptide components found in fraction $<3 \mathrm{kDa}$ by LCMS method

\begin{tabular}{lccll}
\hline Retention Time & $\mathrm{m} / \mathrm{z}$ & Molecular Weight $(\mathrm{Da})$ & $\mathrm{Molecular}$ Formula & Structure Prediction* \\
\hline 2.815 & 231.172 & 230.304 & $\mathrm{C}_{11} \mathrm{H}_{22} \mathrm{~N}_{2} \mathrm{O}_{3}$ & Dipeptide (leu-val) \\
3.072 & 295.131 & 294.303 & $\mathrm{C}_{14} \mathrm{H}_{18} \mathrm{~N}_{2} \mathrm{O}_{5}$ & Dipeptide (glu-phe) \\
4.747 & 571.242 & 570.591 & $\mathrm{C}_{28} \mathrm{H}_{34} \mathrm{~N}_{4} \mathrm{O}_{9}$ & Tetrapeptide (phe-glu-glu-phe) \\
4.976 & 442.198 & 441.436 & $\mathrm{C}_{18} \mathrm{H}_{28} \mathrm{~N}_{5} \mathrm{O}_{8}$ & Tetrapeptide (asn-asp-pro-pro) \\
\hline
\end{tabular}

${ }^{\star}$ The structure prediction does not describe the amino acid sequence, it only describes the amino acid composition prediction of the peptide

$<3 \mathrm{kDa}$ contains of components with high polarity since the column used in this analysis was non-polar C18 column using reverse phase chromatography principle. Therefore the polar components will come out first while the nonpolar components will be longer retained since the stationary phase used in this chromatography method was a non-polar polymer that will interact with non-polar components.

Based on Table 6 and Fig. 1, it can be concluded that by LCMS method was able to detect 4 types of peptide compounds with a molecular weight of each were 230.304 , 294.303, 441.436, and 570.591 Da. These results indicated that the fraction $<3 \mathrm{kDa}$ contained short peptides of less than $1 \mathrm{kDa}$ that corresponded to the molecular size of the analyzed peptide fraction of less than $3 \mathrm{kDa}$. Peptides with short molecular weight are favorable for ACE inhibitory activity because according to Natesh et al. [17], found that large peptide molecules will be limited to enter into the active site of the ACE enzyme.

Based on the structure prediction of the peptide on Table 6, it indicated that all of the peptides might have the potency as ACE inhibitor since all of them composed of hydrophobic amino acid residues (especially when the amino acid position is on the $\mathrm{C}$ terminal position). This is in accordance with the opinion of Cheung et al. [18] that reported that the hydrophobic amino acid residues at the $\mathrm{C}$ terminal position of the peptide molecules contribute to ACE inhibitory activity.

\section{- CONCLUSION}

The results of pigeon pea germination showed that the peak of germination was achieved on the $3^{\text {rd }}$ day, resulting in peptide extract with the highest peptide content due to the resulting of "peak germination peptide". The ACE inhibitory activity of germinated pigeon pea peptide extract was affected by germination time and the highest activity was found on the $4^{\text {th }}$ day. Fractionation by centrifugal ultrafiltration method on this peptide extract showed that the peptide fraction $<3 \mathrm{kDa}$ had the highest ACE inhibitory activity. The characterization result of this fraction $(<3 \mathrm{kDa})$ indicated that the fraction was composed by short peptides with molecular weight less than $1 \mathrm{kDa}$, and was composed with relatively high of hydrophobic amino acid which is 
advantageous for ACE inhibitory activity. Considering the peptide fraction obtained in this study still contained a mixture of several peptides, it is necessary to carry out further purification steps to obtain a single peptide with the highest ACE inhibitory activity.

\section{- ACKNOWLEDGMENTS}

This work was supported by BPPDN Scholarship 2015. The authors also thank Puslabfor Bareskrim POLRI for LCMS analysis.

\section{- REFERENCES}

[1] de Castro, R.J.S., and Sato, H.H., 2015, Biologically active peptides: Processes for their generation, purification and identification, and applications as natural additives in the food and pharmaceutical industries, Food Res. Int., 74, 185-198.

[2] Malaguti, M., Dinelli, G., Leoncini, E., Bregola, V., Bosi, S., Cicero, A.F.G., and Hrelia, S., 2014, Bioactive peptides in cereals and legumes: Agronomical, biochemical and clinical aspects, Int. J. Mol. Sci., 15, 21120-21135.

[3] Sangronis, E., and Machado, C.J., 2007, Influence of germination on the nutritional quality of Phaseolus vulgaris and Cajanus cajan, LWT Food Sci. Technol., 40 (1), 116-120.

[4] Sefatie, R.S., Fatoumata, T., Eric, K., Shi, Y.H., and Le, G., 2013, In vitro antioxidant activities of protein hydrolysate from germinated black soybean (Glycine max L.), Adv. J. Food Sci. Technol., 5 (4), 453-459.

[5] Singh, U., and Jambunathan, R., 1982, Distribution of seed protein fractions and amino acids in different anatomical parts of chickpea (Cicer arietinum $\mathrm{L}$.) and pigeon pea (Cajanus cajan L.), Plant Foods Hum. Nutr., 31 (4), 347-354.

[6] Mandal, P., Misra, T.K., Sarkar, A., Ghosh, A., and Sircar, P.K., 2008, Dynamic peptide profiles of germinating mungbean: In relation to their nature and separation pattern, Indian J. Plant Physiol., 13 (2), 111-117.

[7] Bamdad, F., Dokhani, S., Keramat, J., and Zareie, R., 2009, The impact of germination and in vitro digestion on the formation of Angiotensin
Converting Enzyme (ACE) inhibitory peptides from lentil proteins compared to whey proteins, Int. J. Nutr. Food Eng., 3 (1), 109-119.

[8] Layne, E., 1957, Spectrophotometric and turbidimetric methods for measuring proteins, Methods Enzymol., 3, 447-455.

[9] Cushman, D.W., and Cheung, H.S., 1971, Spectrophotometric assay and properties of the angiotensin-converting enzyme of rabbit lung, Biochem. Pharmacol., 20 (7), 1637-1648.

[10] Siow, H.L., and Gan, C.Y., 2013, Extraction of antioxidative and antihypertensive bioactive peptide from Parkia speciosa seeds, Food Chem., 141 (4), 3435-3442.

[11] Waters, 1993, ACCQ-Fluor Reagent Kit, http://www.waters.com/webassets/cms/support/do cs/wat0052881.pdf.

[12] Waters, 2005, Masslynx 4.1. Getting Starting Guide, Waters Corporation, USA.

[13] Xiao, J.F., Zhou, B., and Ressom, H.W., 2012, Metabolite identification and quantitation in LCMS/MS-based metabolomics, Trends Anal. Chem., 32, 1-14.

[14] Sangronis, E., Rodriguez, M., Cava, R., and Torres, A., 2006, Protein quality of germinating Phaseolus vulgaris, Eur. Food Res. Technol., 222 (1-2), 144-148.

[15] Chinq-Mars, C.D., 2006, Angiotensin converting enzyme inhibitory peptide from the hydrolysis of Pacific Hake fillet by commercial protease, Thesis, British Columbia University.

[16] Ryan, J.T., Ross, R.P., Bolton, D., Fitzgerald, G.F., and Stanton, C., 2011, Bioactive peptide from muscle sources: Meat and fish, Nutrients, 3 (9), 765-791.

[17] Natesh, R., Schwager, S.I.U., Sturrock, E.D., and Achraya, K.R., 2003, Crystal structure of the human angiotensin-converting enzyme-lisinopril complex, Nature, 421 (6922), 551-554.

[18] Cheung, H.S., Wang, F.L., Ondetti, M.A., Sabo, E.F., and Cushman, D.W., 1980, Binding of peptide substrates and inhibitors of angiotensin-converting enzyme. Importance of the $\mathrm{COOH}$-terminal dipeptide sequence, J. Biol. Chem., 255 (2), 401-407. 